\title{
Access for peritoneal dialysis in neonates and infants
}

\author{
M A Lewis, I B Houston, R J Postlethwaite
}

\begin{abstract}
A new catheter for peritoneal dialysis in neonates and infants was used on 28 occasions in 17 patients. Advantages over other catheters included easy safe introduction over a guide wire, absence of early leakage of dialysate, and the ability to change the catheter without creating a second abdominal wound.
\end{abstract}

Acute renal failure is a common complication of severe illness in neonates and infants and the treatment of choice is early peritoneal dialysis. ${ }^{1}$ One difficulty is the introduction of a suitable peritoneal catheter. Several catheters and techniques have previously been described in neonates, ${ }^{2-4}$ all of which require the introduction of a plastic catheter into the peritoneum, either over a trocar (as in adult acute peritoneal dialysis) or over a stylet (as when inserting an intravenous cannula). Acute peritoneal dialysis using a stiff catheter introduced into the peritoneum over a guidewire has been described in adults. ${ }^{5}$ We describe a new catheter specifically for use in neonates and infants, which uses this technique of introduction and which we feel has several advantages over other catheters.

\section{Methods}

CATHETER

The 'Pendlebury' catheter (Medcomp) is based on a percutaneous haemodialysis catheter. It is made of polyurethane, 14 gauge internal diameter, and 5.1 or $8.9 \mathrm{~cm}$ long. There are four side holes, the most proximal being $2.6 \mathrm{~cm}$ from the distal end. The catheter itself is moulded to a short soft plastic extension tube that terminates in a female Luer lock connection. It is introduced by the Seldinger technique over a ' $j$ ' wire, as described below. Free gravitational flow rates of $140 \mathrm{ml} / \mathrm{min}$ at a height of $100 \mathrm{~cm}$ can be achieved, allowing efficient dialysis in children weighing up to $14 \mathrm{~kg}$ with standard volumes.

Royal Manchester Children's Hospital, Department of Child Health M A Lewis I B Houston

Department of Paediatric Nephrology R J Postlethwaite Correspondence to: Dr M A Lewis, Royal Manchester Children's Hospital, Pendlebury, Manchester M27 1HA. Accepted 28 August 1989 INSERTION

After choosing an appropriate site to introduce the catheter, the skin is prepared with a solution containing iodine or chlorhexidine. The best site for introduction will vary from child to child depending on the presence of operation scars or enlargement of organs, or both. On the whole we prefer to introduce the catheter at the level of the umbilicus just lateral to the rectus sheath, but it can be introduced anywhere along a line parallel to the rectus sheath, or in the midline below the umbilicus.

After preparation of the skin, local anaesthetic ( $1 \%$ lignocaine) is injected into the site, and a 22 gauge IV cannula introduced. This is primed with saline and then removed.

The pink hubbed introducer needle is then inserted straight through into the peritoneum. This is flushed with $5 \mathrm{ml}$ normal saline and aspirated to ensure bowel content is not retrieved (fig 1). This needle is left resting in the peritoneum, and the ' $j$ ' tip of the guidewire is straightened using the blue plastic adapter on it (fig 2). This adapter is then placed into the hub of the introducer needle and the wire advanced through the needle into the peritoneum (fig 3).

As the ' $j$ ' end of the wire emerges through the tip of the needle a 'give' is felt as the resistance against the advancing wire is reduced. The wire should now advance a further $1-4 \mathrm{~cm}$ without any resistance. If there is resistance, the tip of the wire might either be in bowel or in subcutaneous tissue, in which case the needle and wire can be removed and the procedure started again. With the wire resting in the peritoneum the blue plastic adapter and needle are removed.

The catheter is now threaded over the wire (fig 4), in preterm infants there is no need to make a skin incision-the catheter can simply be forced through with a 'screwing' action. There is no risk of the catheter causing intraabdominal injury as it will simply follow the wire. In the infant born at full term, and in older infants, a 3-4 mm skin incision around the wire will make passage through the skin easier.

Once the catheter has been inserted the wire is removed, the catheter is connected to a peritoneal dialysis delivery system, and the soft plastic extension of the catheter is taped to the skin.

\section{Results}

Dialysis was carried out in 17 patients ranging from 27 weeks' gestation to $2 \cdot 7$ years of age and from $800 \mathrm{~g}$ to $13 \mathrm{~kg}$ in weight (tables 1 and 2). Ten of the 17 patients were neonates, of whom four had severe respiratory distress complicated by hypoxia and sepsis, three had mainly surgical 

introducer needle into the peritoneum.
Figure I Insertion of the into peritoneum through needle.
Figure 3 Passage of wire
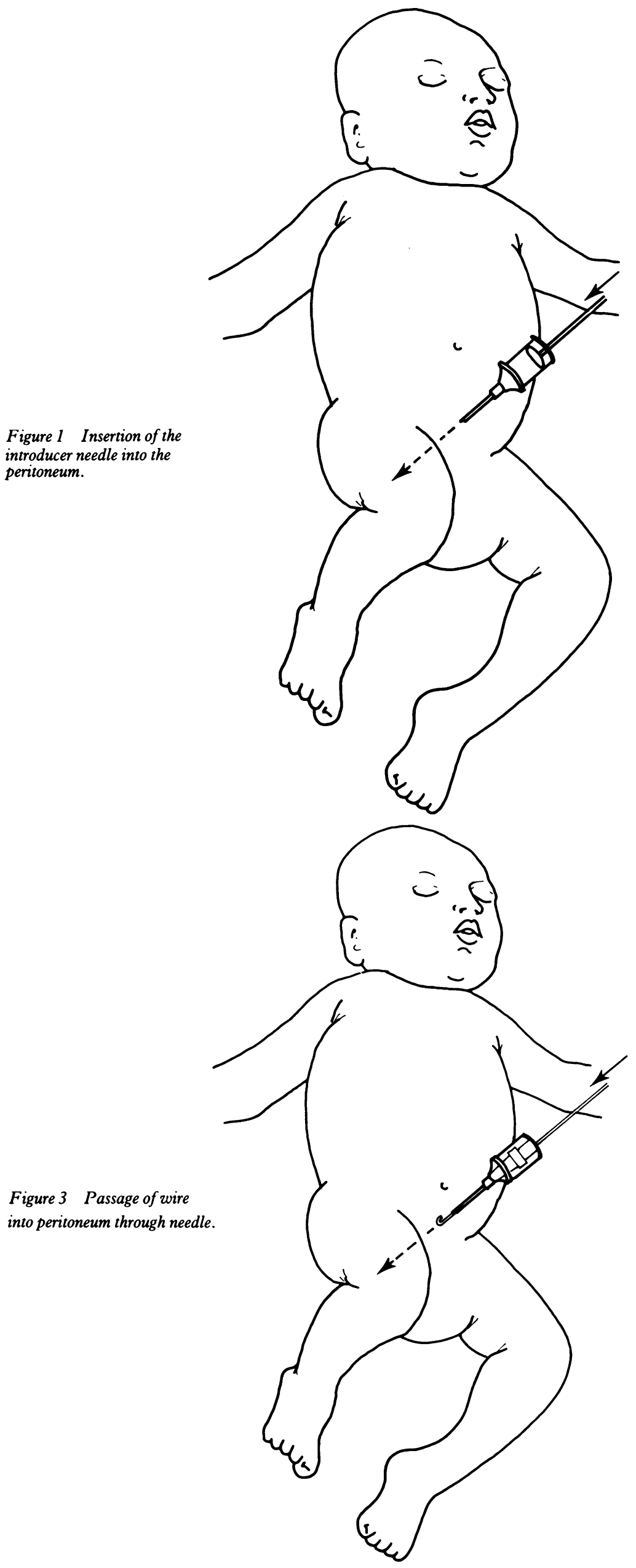

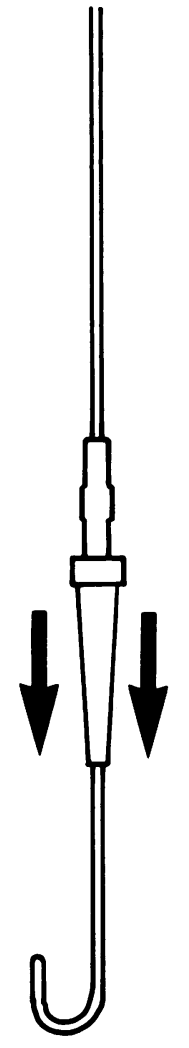

Figure 2 Straightening ' $j$ ' wire with blue plastic adaptor.

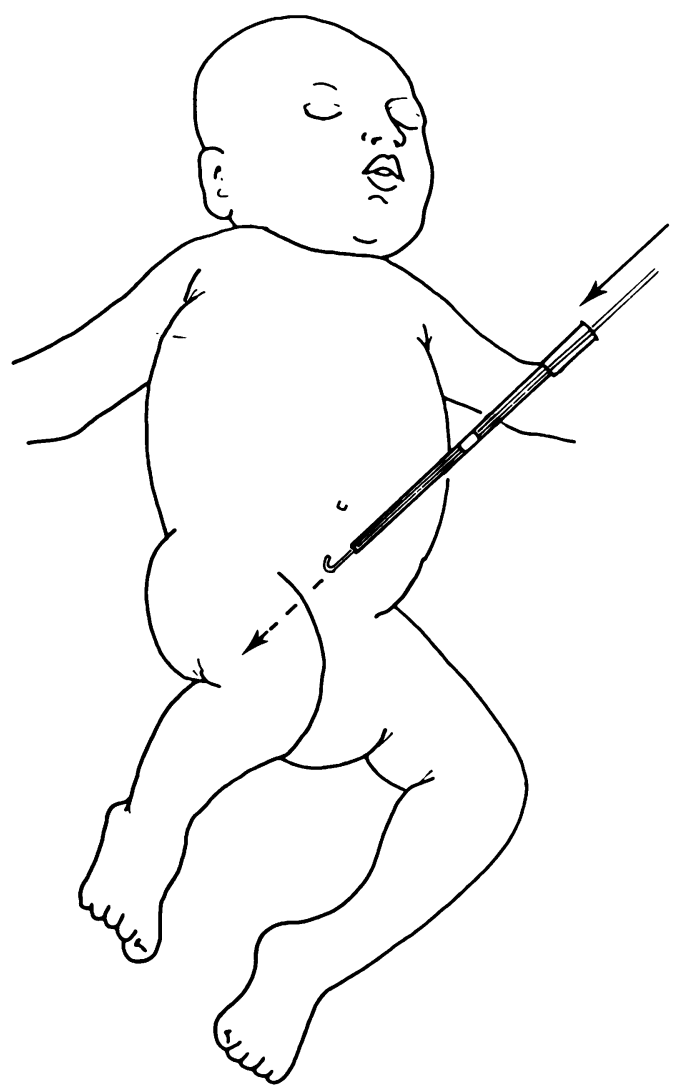

Figure 4 Passage of catheter over wire into peritoneum. 
Table 1 Details of neonates studied

\begin{tabular}{|c|c|c|c|c|c|c|}
\hline $\begin{array}{l}\text { Case } \\
\text { No }\end{array}$ & $\begin{array}{l}\text { Gestation } \\
\text { (weeks) }\end{array}$ & $\begin{array}{l}\text { Age } \\
\text { (days) }\end{array}$ & $\begin{array}{l}\text { Weight } \\
(g)\end{array}$ & Diagnoses & $\begin{array}{l}\text { Duration of } \\
\text { peritoneal dialysis } \\
\text { (days) }\end{array}$ & Outcome \\
\hline 1 & 40 & 27 & 3500 & Aortic thrombosis & $34 \cdot 0$ & $\begin{array}{l}\text { Survived, now in } \\
\text { end stage renal } \\
\text { failure }\end{array}$ \\
\hline 2 & 38 & 28 & 2200 & Hepatorenal failure, undiagnosed cause & $11 \cdot 0$ & Died \\
\hline 3 & 39 & 1 & 2800 & Primary lactic acidosis & $5 \cdot 2$ & Died \\
\hline 4 & 26 & 2 & 800 & $\begin{array}{l}\text { Asphyxia, severe idiopathic respiratory distress } \\
\text { syndrome }\end{array}$ & $0 \cdot 21$ & $\begin{array}{l}\text { Underwent diuresis } \\
\text { died six days } \\
\text { later }\end{array}$ \\
\hline 5 & 27 & 11 & 1100 & Septicaemia, disseminated intravascular coagulation & 0.33 & Died \\
\hline 6 & 37 & 27 & 1600 & Gastroschisis, disseminated intravascular coagulation & 0.5 & Died \\
\hline 7 & 28 & 11 & 1100 & Necrotising enterocolitis, septicaemia & $6 \cdot 0$ & Died \\
\hline 8 & 27 & 2 & 1000 & $\begin{array}{l}\text { Asphyxia, severe idiopathic respiratory distress } \\
\text { syndrome }\end{array}$ & 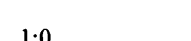 & Die \\
\hline \multirow[t]{2}{*}{9} & \multirow[t]{2}{*}{30} & \multirow[t]{2}{*}{1} & \multirow[t]{2}{*}{1500} & \multirow{3}{*}{$\begin{array}{l}\text { Idiopathic respiratory distress syndrome, } \\
\text { hypotension } \\
\text { Exomphalos, septicaemia }\end{array}$} & & \multirow{3}{*}{$\begin{array}{l}\text { Alive and well } \\
\text { Died }\end{array}$} \\
\hline & & & & & $3 \cdot 0$ & \\
\hline 10 & 32 & 9 & 1800 & & $9 \cdot 0$ & \\
\hline
\end{tabular}

Table 2 Details of older infants studied

\begin{tabular}{|c|c|c|c|c|c|}
\hline $\begin{array}{l}\text { Case } \\
\text { No }\end{array}$ & $\begin{array}{l}\text { Age } \\
\text { (months) }\end{array}$ & $\begin{array}{l}\text { Weight } \\
(\mathrm{kg})\end{array}$ & Diagnoses & $\begin{array}{l}\text { Duration of } \\
\text { peritoneal dialysis } \\
\text { (days) }\end{array}$ & Outcome \\
\hline $\begin{array}{l}11 \\
12 \\
13 \\
14 \\
15 \\
16 \\
17\end{array}$ & $\begin{array}{r}32 \\
15 \\
3 \\
1 \\
10 \\
6 \\
1 \cdot 7\end{array}$ & $\begin{array}{r}13 \cdot 0 \\
10 \cdot 0 \\
5 \cdot 1 \\
4 \cdot 2 \\
7 \cdot 9 \\
4 \cdot 4 \\
5 \cdot 0\end{array}$ & $\begin{array}{l}\text { Haemolytic uraemic syndrome, septicaemia } \\
\text { Haemolytic uraemic syndrome } \\
\text { Haemolytic uraemic syndrome } \\
\text { Hypernatraemic dehydration } \\
\text { Haemolytic uraemic syndrome } \\
\text { Septicaemia, disseminated intravascular coagulation } \\
\text { Multisystem failure-? 'cot death' }\end{array}$ & $\begin{array}{r}3 \cdot 0 \\
11 \cdot 8 \\
5 \cdot 0 \\
0 \cdot 6 \\
10 \cdot 8 \\
2 \cdot 0 \\
1 \cdot 9\end{array}$ & $\begin{array}{l}\text { Died } \\
\text { Alive and well } \\
\text { Alive and well } \\
\text { Alive and well } \\
\text { Alive and well } \\
\text { Died } \\
\text { Died }\end{array}$ \\
\hline
\end{tabular}

complication rate of 0.21 episodes/patient day. Blockage or poor drainage occurred with 12 catheters but in only six was either the reason for removal. There was no early leakage of dialysate (within 48 hours of insertion). Some late leakage occurred with seven catheters, although it was an appreciable amount in only four cases. There were three episodes of peritonitis, two of which occurred in one patient. Twenty eight catheters were used of which 12 $(43 \%)$ were removed because of problems: six because of blockage, four because of late leakage, and two because of peritonitis. The mean duration of function of these catheters was $4 \cdot 1$ days (range $0 \cdot 5$ to 11 ). For the 16 catheters removed electively the mean duration of function was three days (range $0 \cdot 21$ to 9 ).

One infant with repaired gastroschisis who weighed $1060 \mathrm{~g}$ developed peritonitis, septicaemia, and an ileus, after a catheter had eroded into the wall of diseased bowel. This was discovered at necropsy; the catheter had worked well until a few hours before death when treatment was electively stopped. There were no other cases of injury, even in infants who had had abdominal operations.

\section{Discussion}

The 'Pendlebury' catheter has several advantages. It is soft and pliable (particularly at body temperature), but it does not kink. Using a ' $j$ ' wire makes introduction safer because the wire will not advance easily if the tip of the introducing needle is in subcutaneous tissue or in a viscus rather than in the peritoneal cavity. This means that priming of the abdomen is not essential and can be omitted if it is felt the patient would not tolerate high intra-abdominal pressures. The tissues are stretched around the catheter so that there is a tight fit and no early leakage. After it has been sited the catheter is taped flat to the skin, so making nursing easier, particularly in mobile infants. The catheter is small enough for one to be inserted on each side of the abdomen and continuous cross flow dialysis carried out.

Blockage or poor drainage can be managed either by flushing with saline, or, if this is unsuccessful, by passing a guidewire through the catheter until it is beyond the tip, removing the catheter and inserting a new catheter over the guidewire. This almost invariably establishes good flow without the problem of leakage from an old catheter site.

There are few data available about the incidence of complications in this age group with other peritoneal dialysis catheters. We have found that thin walled intravenous cannulas block and kink easily. The same applies to the 'Wallace' peritoneal dialysis catheter, ${ }^{2}$ which has two additional problems. Being introduced over a sharp stylet gives almost no 'feel' of where one is in the abdomen, and having side holes extending back $5 \mathrm{~cm}$ from the tip makes full introduction difficult in a small abdomen. Small neonatal chest drains are just as difficult to introduce into infant abdomens as standard trocar catheters.

Compared with catheters introduced over trocars, the incidence of problems in our group was similar to that found by Wong and Geary in their group of 33 patients (mean age 3.4 years, mean weight $15 \cdot 1 \mathrm{~kg}$ ) treated with Trocath catheters, ${ }^{6}$ despite the fact that our patients were appreciably smaller and younger (table 3 ). Obstruction to flow seems to be more common with the Pendelbury catheter, but is more easily dealt with. Eight out of 12 patients in the series described by Wong and Geary required removal of their catheters because of obstruction to flow, compared with four out of 10 in our series. 
Table 3 Comparison of the results obtained using the Pendlebury and the Trocath catheter

\begin{tabular}{llc}
\hline & $\begin{array}{l}\text { Trocath } \\
\text { catheter } \\
(n=33)\end{array}$ & $\begin{array}{l}\text { Pendlebury } \\
\text { catheter } \\
(n=17)\end{array}$ \\
\hline $\begin{array}{l}\text { Mean duration of } \\
\text { dialysis (days) }\end{array}$ & $7 \cdot 1$ & $6 \cdot 2$ \\
$\begin{array}{l}\text { Overall complication rate } \\
\text { (episodes/patient/day) }\end{array}$ & $0 \cdot 19$ & $0 \cdot 21$ \\
$\begin{array}{l}\text { No (\%) patients having } \\
\text { catheter removed } \\
\text { because of problems }\end{array}$ & $19(58)$ & $8(47)$ \\
$\begin{array}{l}\text { No (\%) patients requiring } \\
\text { two or more catheters }\end{array}$ & $12(36)$ & $7(41)$ \\
$\begin{array}{l}\text { No (\%) with leakage of } \\
\text { dialysate }\end{array}$ & $12(36)$ & $6(35)$ \\
$\begin{array}{l}\text { No (\%) with obstruction } \\
\text { to flow }\end{array}$ & $12(36)$ & $10(59)$ \\
No (\%) with peritonitis & $5(15)$ & $2(12)$ \\
\hline
\end{tabular}

Leakage of dialysate was equally as common in both groups, but did not occur with the Pendlebury catheter until after four days of dialysis, whereas with the Trocath catheters early leakage occurred in four patients. Early leakage is a much more difficult problem than late leakage, as it can prevent successful dialysis at an early stage when the patient's biochemical state is at its worst and dialysis is most required.
We feel that the Pendlebury catheter is an important improvement on other catheters that are available for peritoneal dialysis in neonates and children up to 18 months old, judged to a large extent on clinical impression. The time has now come to carry out a controlled trial of different catheters and means of peritoneal dialysis in small ill infants.

We thank Dr ML Chiswick and Dr DG Sims from the Regional Neonatal Medicine Unit, and Mr A Bianchi and Miss C Doig from the Regional Neonatal Surgical Unit, St Mary's Hospital, Manchester, for allowing us to include their patients in this study.

1 Brocklebank JT. Renal failure in the newly born. Arch Dis Child 1988;63:991-4.

2 Donaldson MDC, Spurgeon P, Haycock GB, Chantler C. Peritoneal dialysis in infants. $B r$ Med f 1983:286:759-60. Davies JG. Two catheter technique in neonatal peritoneal dialysis. Arch Dis Child 1984;59:492.

4 Steele BT, Vigneux A, Blatz S, Flavin M, Paes B. Acute peritoneal dialysis in infants weighing $<1500 \mathrm{~g}$. $\mathcal{F}$ Pediatr 1987;110:126-9.

5 Nakanishi T, Yanase M, Fujii M, Tanaka Y, Orita Y, Abe H. New acute peritoneal dialysis technique: wire guide insertion and long term indwelling of peritoneal catheter. insertion and long term ind

6 Wong SN, Geary DF. Comparison of temporary and permanent catheters for acute peritoneal dialysis. Arch Dis hild 1988;63:827-31. 